\title{
PENGARUH MODEL PEMBELAJARAN DAN GAYA BELAJAR TERHADAP KEMAMPUAN BERPIKIR KRITIS DAN PRESTASI BELAJAR PPKn PESERTA DIDIK SMP
}

\section{THE INFLUENCE OF LEARNING MODEL AND LEARNING STYLE ON CRITICAL THINKING ABILITY AND LEARNING ACHIEVEMENT OF PPKn OF SMP CLASS VIII}

\author{
Fitri Mutmainnah, Abdul Gafur \\ Prodi PPKn, Universitas Negeri Yogyakarta \\ v3_ant@yahoo.co.id, agafur68@gmail.com
}

\begin{abstract}
Abstrak
Penelitian ini bertujuan untuk mengetahui: (1) perbedaan pengaruh antara model discovery learning dengan model PBL terhadap kemampuan berpikir kritis dan prestasi belajar PPKn, (2) perbedaan pengaruh antara model discovery learning dan model PBL terhadap kemampuan berpikir kritis dan prestasi belajar PPKn pada gaya belajar visual dan gaya belajar auditorial, dan (3) ada tidaknya interaksi antara model pembelajaran dengan gaya belajar terhadap kemampuan berpikir kritis dan prestasi belajar PPKn. Penelitian ini merupakan penelitian quasi experimen desain faktorial $2 \times 2$. Pengumpulan data menggunakan tes dan angket. Sampel dalam penelitian ini adalah peserta didik kelas VIII SMP Negeri 4 Kalasan. Hasil penelitian menunjukkan (1) terdapat perbedaan pengaruh antara model discovery learning dan model PBL terhadap kemampuan berpikir kritis $(0,002<0,05)$ dan prestasi belajar PPKn $(0,003<0,05)$; (2) terdapat perbedaan pengaruh antara model discovery learning dan model PBL terhadap kemampuan berpikir kritis $(0,044<0,05)$ dan prestasi belajar PPKn $(0,006<0,05)$ pada kelompok peserta didik gaya belajar visual dan gaya belajar auditorial; dan (3) tidak terdapat interaksi yang signifikan antara model pembelajaran dan gaya belajar terhadap kemampuan berpikir kritis $(0,585>0,05)$ dan prestasi belajar PPKn $(0,229>0,05)$. Pembelajaran PPKn dengan model discovery learning pada kelompok peserta didik gaya belajar visual lebih unggul daripada model PBL baik kelompok peserta didik gaya belajar visual maupun auditorial terhadap kemampuan berpikir kritis dan prestasi belajar PPKn.
\end{abstract}

Kata kunci: model pembelajaran, gaya belajar, kemampuan berpikir kritis, prestasi belajar PPKn

\begin{abstract}
This research aimed to reveal: (1) the difference of influence between discovery learning model and PBL model on critical thinking ability and learning achievement of PPKn, (2) the difference of influence between discovery learning model and PBL model on critical thinking ability and learning achievement PPKn on visual and auditorial learning styles, and (3) interaction of influence between learning model and learning style on critical thinking ability and learning achievement of PPKn. This research is a quasi experimental research methods using the $2 \times 2$ factorial design. The data were collected using a cognitive test and questionnaire. The sample in this research is the students of class VIII SMP Negeri 4 Kalasan. The result of this research showed that: (1) there was a difference between discovery learning model and PBL model on critical thinking ability $(0.002<0.05)$ and learning achievement of PPKn $(0.003<0.05)$; (2) there was a difference between discovery learning model and PBL model on critical thinking ability $(0.044<0.05)$ and learning achievement of PPKn $(0.006<0.05)$ in a group of learners of visual and auditorial learning styles; and (3) there was no significant interaction between learning model and learning style on critical thinking ability $(0.585>$ $0.05)$ and learning achievement of PPKn $(0.229>0.05)$. The learning of PPKn with the discovery learning model in a group of learners visual learning style is superior to the PBL model in both the group of learners of visual and auditorial learning styles on critical thinking ability and learning achievement of PPKn.
\end{abstract}

Keywords: learning model, learning style, critical thinking ability, learning achievement of PPKn 


\section{Pendahuluan}

Pendidikan Kewarganegaraan merupakan bagian utuh dari sistem pendidikan nasional. Untuk mengakomodasikan perkembangan baru dan perwujudan pendidikan sebagai proses pencerdasan kehidupan bangsa dalam arti utuh dan luas, substansi dan nama mata pelajaran yang sebelumnya Pendidikan Kewarganegaraan (PKn) maka dikemas dalam Kurikulum 2013 menjadi mata pelajaran Pendidikan Pancasila dan Kewarganegaraan (selanjutnya disebut PPKn).

Dalam Peraturan Menteri Pendidikan dan Kebudayaan Nomor 58 Tahun 2014 tentang Kurikulum 2013 SMP/MTs Lampiran III disebutkan bahwa tujuan khusus PPKn agar peserta didik mampu berpikir secara kritis, rasional, dan kreatif serta memiliki semangat kebangsaan serta cinta tanah air yang dijiwai oleh nilai-nilai Pancasila, Undang-Undang Dasar Negara Republik Indonesia Tahun 1945, semangat Bhinneka Tunggal Ika, dan komitmen Negara Kesatuan Republik Indonesia. Berdasarkan tujuan tersebut kemampuan berpikir kritis sangat penting dalam proses pembelajaran PPKn, terutama dalam memberikan tanggapan maupun kritikan terhadap isu-isu kewarganegaraan yang sedang berkembang baik dalam kehidupan bermasyarakat maupun kehidupan berbangsa dan bernegara.

Berdasarkan kajian yang dilakukan oleh lembaga yang bernama Partnership for $21^{\text {st }}$ century skills (2010, p.1) dinyatakan bahwa keterampilan berpikir kritis merupakan salah satu keterampilan esensi yang harus dimiliki oleh peserta didik. Keterampilan ini sangat bermanfaat bagi peserta didik dalam menghadapi kondisi yang ada di masyarakat saat ini. Di dalam perkembangan teknologi informasi dan komunikasi yang begitu cepat di abad ke-21 telah banyak membawa dampak, baik positif maupun negatif. Peserta didik dapat dengan mudah dan cepat menerima beragam informasi yang datang dari berbagai belahan penjuru dunia. Informasi yang beragam tersebut secara langsung maupun tidak langsung dapat mempengaruhi dan mengubah sikap serta perilaku peserta didik. Oleh karena itu, diperlukan filter agar informasi yang datang tidak begitu saja diterima. Dengan keterampilan berpikir kritis peserta didik diharapkan mampu memilah mana informasi yang bermanfaat atau tidak bagi dirinya.
Pentingnya mengembangkan kemampuan berpikir kritis untuk peserta didik di sekolah diakui oleh sejumlah ahli pendidikan. Brandt (Sapriya, 2015, p.145) menyatakan bahwa saat ini belum banyak muncul kesadaran yang tinggi di kalangan pendidik di persekolahan untuk mengajar para peserta didik tentang kondisi dunia yang semakin berkembang pesat yang menuntut adanya respon dengan pemikiran secara kritis. Di sekolah, pengembangan keterampilan berpikir kritis peserta didik belum sepenuhnya difasilitasi melalui kegiatan pembelajaran yang ada. Lebih lanjut, Brooks \& Brooks (Santrock, 2011, p.44) mengungkapkan bahwa terlalu sedikit sekolah yang mengajarkan peserta didiknya untuk berpikir kritis dan mendalam.

Sehubungan dengan pelaksanaan pendidikan formal di sekolah, maka peran guru sangat menentukan keberhasilan kemampuan berpikir kritis peserta didik. Akan tetapi dalam tataran praktik, proses pembelajaran PPKn belum sepenuhnya mendorong peserta didik untuk mengembangkan kemampuan berpikir kritis. Dalam hal ini seharusnya PPKn diajarkan secara interaktif, isi dan proses dikaitkan dengan kehidupan nyata, diselenggarakan dalam suasana demokratis, diupayakan mewadahi keanekaragaman sosial budaya serta bersama-sama dikembangkan oleh sekolah, orang tua, masyarakat dan negara (Saputra, 2012, p.155). Dengan demikian kesenjangan yang melahirkan kontroversi atau sebuah paradoksal antara apa yang didapat di sekolah dengan kondisi real di masyarakat dapat diminimalisir.

Merujuk dari permasalahan di atas, secara tidak langsung berpengaruh pada pencapaian prestasi belajar peserta didik. Adanya program remedial yang diselenggarakan di sekolah dapat menjadi tolok ukur utama masih kurangnya prestasi belajar peserta didik. Dimyati dan Mujiono (2006, p.34) menjelaskan bahwa prestasi belajar merupakan hubungan antara hasil belajar yang dilakukan oleh peserta didik dengan tindak mengajar yang dilakukan oleh guru. Dalam hal ini prestasi belajar merupakan akibat dari proses mengajar. Prestasi belajar sebagai hasil belajar juga berfungsi sebagai salah satu indikator pencapaian tujuan pembelajaran di kelas.

Dalam mencapai tujuan pembelajaran, guru dituntut kreatif dalam melaksanakan pembelajaran di kelas. Selain itu faktor peserta didik juga tidak kalah penting menjadi 
pertimbangan dalam proses pembelajaran. Dick \& Carey (Halim, 2012, p.143) menyatakan bahwa seorang guru hendaklah mampu mengenal dan mengetahui karakteristik peserta didik. Sebab dengan pemahaman yang baik terhadap karakteristik peserta didik, guru dapat menyesuaikan model pembelajaran yang digunakannya sehingga sangat mempengaruhi keberhasilan proses belajar peserta didik.

Salah satu karakteristik peserta didik dapat dilihat dari gaya belajar peserta didik. Gaya belajar merupakan bagaimana cara peserta didik menyerap informasi yang diberikan oleh guru dan bagaimana peserta didik mengatur serta mengolah informasi tersebut. Kemampuan menyerap informasi setiap peserta didik cenderung berbeda berdasarkan modalitas belajarnya. Guru diharapkan mampu memahami gaya belajar peserta didiknya agar dapat memfasilitasi lingkungan belajar yang sesuai dengan gaya belajar mereka.

Dalam mengajarkan PPKn membutuhkan keterampilan seorang guru dalam memilih model pembelajaran yang tepat digunakan dalam proses pembelajaran. Pemilihan model pembelajaran yang tepat akan mempengaruhi suasana belajar menjadi menyenangkan dan memungkinkan peserta didik untuk mengembangkan kreatifitasnya. Seperti yang diungkapkan oleh Djamarah \& Zein (2006, p.158) bahwa penggunaan model mengajar yang bervariasi dapat menggairahkan belajar anak didik, pada suatu kondisi tertentu seorang anak akan merasa bosan dengan model ceramah maka guru perlu mengalihkan suasana dengan menggunakan model lain seperti metode tanya jawab, diskusi atau model penugasan sehingga kebosanan dapat terobati dan suasana kegiatan pengajaran jauh dari kelesuan.

Salah satu model pembelajaran yang dapat digunakan oleh guru untuk mengembangkan kemampuan berpikir kritis sekaligus mencapai prestasi belajar yang optimal adalah model pembelajaran aktif (active learning). Pembelajaran aktif merupakan pembelajaran yang mengajak peserta didik untuk belajar secara aktif. Ketika peserta didik belajar secara aktif, berarti mereka yang mendominasi aktivitas pembelajaran (student centered). Model pembelajaran aktif yang dapat diterapkan adalah model pembelajaran discovery learning dan model pembelajaran problem based learning (PBL).

\section{Model Pembelajaran}

Inovasi pembelajaran PPKn sangat dibutuhkan. Model pembelajaran yang dapat digunakan untuk mengajarkan kemampuan berpikir kritis sekaligus meningkatkan prestasi belajar adalah discovery learning dan PBL. Joolingen (1999, p.386) menyatakan bahwa discovery learning merupakan model pembelajaran dimana peserta didik membangun pengetahuan mereka sendiri dengan bereksperimen sesuai dengan pengetahuan peserta didik sendiri serta menyimpulkan hasil dari pembelajaran yang telah diperoleh.

Dalam menerapkan model discovery learning guru harus menciptakan situasi belajar yang problematis, menstimulus peserta didik dengan pertanyaan-pertanyaan, mendorong peserta didik mencari jawaban sendiri serta melakukan eksperimen untuk menemukan suatu konsep atau teori. Pada akhirnya melalui model discovery learning diharapkan dapat meningkatkan penalaran dan kemampuan untuk berpikir secara bebas dan melatih keterampilan kognitif peserta didik dengan cara menemukan dan memecahkan masalah yang ditemui dengan pengetahuan yang telah dimiliki dan menghasilkan pengetahuan yang benar-benar bermakna bagi dirinya.

Langkah-langkah model discovery learning menurut Mubarok \& Sulistyo (2014, p.217) diawali dengan guru memberikan pertanyaan yang merangsang berpikir peserta didik dan mendorongnya untuk membaca buku dan melakukan aktivitas belajar lainnya. Selanjutnya, guru memberikan kesempatan kepada peserta didik untuk mengidentifikasi sebanyak mungkin masalah yang relevan dengan bahan pelajaran dan merumuskannya dalam bentuk hipotesis. Kemudian, guru memberikan kesempatan kepada peserta didik mengumpulkan informasi yang relevan untuk membuktikan benar tidaknya hipotesis tersebut yang dilanjutkan dengan pengolahan data yang diperoleh peserta didik melalui wawancara, observasi dan sumber data lainnya. Lalu, guru melakukan pemeriksaan dengan cermat untuk membuktikan benar tidaknya hipotesis yang ditetapkan dengan hasil dan pengolahan data. Selanjutnya, guru dan peserta didik menarik kesimpulan untuk dijadikan prinsip umum yang berlaku untuk semua masalah yang sama.

Selain model discovery learning, model PBL juga model yang dikembangkan berdasarkan pendekatan social constructivism. 
Model PBL merupakan salah satu model pengajaran yang memungkinkan peserta didik membangun skema pengetahuan mereka sendiri (Fatade, Mogari, \& Arigbabu, 2013, p.29). Model PBL menekankan pada posisi peserta didik sebagai pembelajar yang aktif dalam menerima pengetahuan, sebagai pemecah masalah yang bisa mengembangkan pengetahuan dan strategi pemecahan masalah dalam disiplin tertentu untuk menghadapi masalah yang terjadi di dunia nyata (Shen, Lee, \& Tsai, 2007, p.148).

Langkah-langkah model PBL menurut Dewey (Sanjaya, 2013: 217) meliputi: 1) merumuskan masalah untuk menentukan masalah yang akan dipecahkan, 2) menganalisis masalah dengan meninjau masalah secara kritis dari berbagai sudut pandang, 3) merumuskan hipotesis, 4) mengumpulkan data, 5) menguji hipotesis dengan mengambil atau merumuskan kesimpulan sesuai dengan hipotesis yang diajukan, 6) merumuskan rekomendasi pemecahan masalah. Dengan penerapan model PBL diharapkan peserta didik memperoleh keterampilan berpikir kreatif dan keterampilan profesional karena dapat memecahkan masalah dalam situasi interdisipliner dan kehidupan nyata.

\section{Gaya Belajar}

Gilakjani (2012, p.105) mendefinikan gaya belajar sebagai cara yang paling disukai dan paling dominan dalam proses belajar, dimana peserta didik dapat menerima, menyerap, mengatur, dan mengolah informasi yang didapatkan. Gaya belajar peserta didik berbeda-beda tergantung pada kebiasaan dari peserta didik. DePorter \& Hernacki (2015, p.116) menyebutkan bahwa gaya belajar peserta didik dapat dibagi menjadi tiga, yaitu visual, auditorial dan kinestetik. Namun dalam penelitian ini hanya akan menggunakan dua gaya belajar peserta didik saja, yaitu visual dan auditorial. Hal ini dikarenakan dalam pembelajaran PPKn, peserta didik cenderung menggunakan gaya belajar visual dan auditorial,

Menurut Tutton (2013, p.8) gaya belajar visual merupakan gaya belajar yang disukai melalui melihat dan menghafal komponen visual. Dalam menyerap informasi umumnya peserta didik bergaya belajar visual menerapkan strategi penglihatan yang tajam. Peserta didik lebih mudah menangkap informasi lewat materi bergambar. Selain itu, peserta didik memiliki kepekaan yang kuat terhadap warna dan pemahaman yang cukup terhadap artistik.

Gaya belajar auditorial merupakan gaya belajar yang mengandalkan pada pendengaran (DePorter \& Hernacki, 2015, p.114). Dalam menyerap informasi umumnya orang bergaya belajar auditorial menerapkan strategi pendengaran yang kuat dengan suara dan ungkapan yang berciri pendengaran.

\section{Kemampuan Berpikir Kritis}

Goodson \& Rohani (1998, p.1) menyebutkan bahwa berpikir kritis termasuk dalam kategori higher order thinking skills yang merupakan kemampuan keterampilan berpikir tingkat tinggi sebagai modal peserta didik menjadi warga negara muda dalam menyelesaikan masalah. Lebih lanjut Lewis \& Smith (1993, p.134) menyatakan bahwa dengan mengacu pada teori higher order thinking skill, telah ditetapkan tiga jenis berpikir kritis, yakni berpikir kritis sebagai pemecahan masalah, berpikir kritis sebagai evaluasi dan penilaian, dan berpikir kritis sebagai kombinasi antara evaluasi dan penyelesaian masalah. Sedangkan Johnson (1999, p.100) menyatakan bahwa berpikir kritis merupakan sebuah proses yang terarah dengan jelas yang digunakan dalam kegiatan mental seperti memecahkan masalah, mengambil keputusan, membujuk, menganalisis asumsi, dan melakukan penelitian ilmiah. Berpikir kritis memungkinkan peserta didik untuk mempelajari masalah secara sistematis, menghadapi berjuta tantangan dengan cara yang terorganisasi, merumuskan pertanyaan inovatis, dan merancang solusi orisional.

Berpikir kritis sangat penting bagi peserta didik, dengan kemampuan berpikir kritis ini peserta didik mampu bersikap rasional dalam suatu ide pemikiran, memilih alternatif pilihan yang terbaik bagi dirinya, bahkan mampu mengevaluasi pelaksanaan atau praktik dari suatu pemikiran-pemikiran baru. Philips et al. menyebutkan dalam mengukur keterampilan berpikir kritis perlu mengembangkan lima subskala, yakni analisis, evaluasi, kesimpulan, pemikiran deduktif, serta pemikiran induktif (Afrizon, Ratnawulan, \& Fauzi, 2012, p.12).

\section{Prestasi Belajar PPKn}

Syah (2013, p.141) mendefinisikan prestasi sebagai tingkat keberhasilan peserta didik mencapai tujuan yang telah ditetapkan dalam sebuah program. Sedangkan Jhonson (2002, p.8) mendefinisikan prestasi 
berkembang menurut tiga hubungan yaitu 1) prestasi yang berhubungan dengan tingkah laku, 2) prestasi yang berhubungan dengan hasil dan 3) prestasi yang berhubungan dengan sikap dan waktu. Prestasi dapat dipahami sebagai sebuah standar serta didefinisikan sebagai hasil akademik yang diputuskan menurut kriteria mutlak atau kriteria pembanding.

Prestasi merupakan suatu hal yang diperlukan untuk mengetahui perubahan yang terjadi selama melakukan kegiatan belajar. Maslow berpendapat bahwa prestasi belajar di sekolah merupakan salah satu tujuan yang layak dan penting untuk pendidikan yang merupakan pengalaman puncak (Kyriacou, 2009, p.26). Dalam penelitian ini, prestasi belajar PPKn merupakan hasil belajar peserta didik dari materi PPKn yang telah dipelajari dan dapat diketahui melalui pengukuran dengan alat ukur yang disebut tes hasil belajar. Selanjutnya, dari tes hasil belajar akan menunjukkan sejauh mana materi yang diberikan dikuasai atau dipahami oleh peserta didik setelah proses pembelajaran berlangsung.

\section{Metode Penelitian}

Penelitian ini merupakan penelitian yang menggunakan pendekatan kuantitatif dengan jenis penelitian eksperimen semu (quasi experiment). Desain penelitian menggunakan desain faktorial $2 \times 2$. Kelas yang digunakan dalam penelitian ini terdiri dari empat kelas eksperimen. Kelas eksperimen 1 didesain menggunakan pembelajaran PPKn dengan model discovery learning yang dikontrol dengan gaya belajar visual. Kelas eksperimen 2 menggunakan pembelajaran PPKn dengan model discovery learning yang dikontrol dengan gaya belajar auditorial. Kelas eksperimen 3 menggunakan pembelajaran PPKn dengan model PBL yang dikontrol dengan gaya belajar visual. Kelas eksperimen 4 menggunakan pembelajaran PPKn dengan model PBL yang dikontrol dengan gaya belajar auditorial.

Penelitian ini dilaksanakan di SMP Negeri 4 Kalasan Yogyakarta. Waktu penelitian dilaksanakan pada bulan Januari 2017 sampai dengan bulan Februari 2017. Materi yang digunakan untuk penelitian tentang "Hak Asasi Manusia" pada Bab Lima kelas VIII semester genap.

Populasi dalam penelitian ini adalah seluruh peserta didik SMP Negeri 4 Kalasan tahun pelajaran 2016/2017. Sampel penelitian ini menggunakan teknik purposive sampling. Sampel yang dibutuhkan terdiri dari empat kelas yakni keseluruhan kelas dari kelas VIII. Masing-masing kelas di uji dengan memberikan pretest dan hasil pretest menunjukkan bahwa kelas VIII memiliki karakteristik hampir setara serta stabil. Untuk menentukan klasifikasi kelas menggunakan teknik undian, sehingga diketahui kelompok kelas yang mendapat perlakuan menggunakan model discovery learning dan model PBL.

Teknik pengumpulan data penelitian ini menggunakan angket dan tes. Instrumen yang digunakan untuk mengumpulkan data adalah lembar soal tes dan lembar angket. Lembar angket digunakan untuk mengelompokkan peserta didik berdasarkan tipe gaya belajarnya dan lembar soal tes digunakan untuk menguji kemampuan berpikir kritis dan prestasi belajar PPKn peserta didik.

Data diolah dengan cara menghitung skor pada instrumen penelitian. Setelah itu melakukan uji validitas, reliabilitas instrumen, uji analisis butir soal, uji normalitas, uji homogenitas dan uji hipotesis. Validitas instrumen tes menggunakan validitas isi dengan cara meminta pertimbangan para ahli (judgment expert) yang kemudian diujicobakan kepada peserta didik di luar subjek penelitian. Item soal dinyatakan valid apabila $r$ hitung lebih besar dari $r$ tabel. Selanjutnya reliabilitas instrumen menggunakan koefisien Cronbach's Alpha. Sedangkan analisis butir soal yang digunakan dalam adalah tingkat kesukaran soal dan analisis daya beda dengan menggunakan software AnBuso 4,4.

Uji normalitas yang digunakan dalam penelitian mengacu pada hasil KolmogorofSmirnov. Uji homogenitas mengacu pada hasil Levene test. Selanjutnya uji hipotesis dengan uji analisis varians dua jalur (Two-way Anova) dengan taraf signifikansi 0,05. Hartono (2014, p.176) menyebutkan bahwa uji analisis varians dua jalur digunakan untuk mengetahui ada tidaknya pengaruh antara dua variabel bebas, yaitu model discovery learning dan model PBL dengan variabel moderat gaya belajar yang memiliki dua kategori yaitu gaya belajar visual dan gaya belajar auditorial. Melalui analisis varians dua jalur diharapkan dapat menemukan perbedaan pengaruh dari penerapan model discovery learning dan model PBL ditinjau dari gaya belajar terhadap kemampuan berpikir kritis dan prestasi belajar PPKn peserta didik. 
Analisis data menggunakan bantuan program SPSS versi 24.0.

\section{Hasil Penelitian dan Pembahasan}

Hasil Penelitian

Penelitian ini menyajikan perbedaan hasil kemampuan berpikir kritis dan prestasi belajar PPKn pada pembelajaran dengan menggunakan model discovery learning dan model PBL yang dikontrol dengan gaya belajar visual dan auditorial. Pada aspek kemampuan berpikir kritis, soal yang digunakan berjumlah 5 butir soal essay. Pada aspek prestasi belajar PPKn menggunakan 25 butir soal pilihan ganda. Terdapat empat kelas yang digunakan dalam penelitian ini. Masing-masing kelas eksperimen terdiri dari 20 peserta didik yang dikelompokkan berdasarkan kecenderungan gaya belajarnya.

Kelas eksperimen 1 merupakan kelas yang menggunakan model pembelajaran PBL dengan gaya belajar visual. Adapun hasil penelitian pada aspek kemampuan berpikir kritis dan prestasi belajar PPKn dapat dilihat pada Tabel 1.

Tabel 1. Perbedaan Hasil Pretest dan Posttest pada Kelas Eksperimen 1

\begin{tabular}{|c|c|c|}
\hline Jenis Tes & Mean & STD \\
\hline $\begin{array}{l}\text { Pretest kemampuan } \\
\text { berpikir kritis }\end{array}$ & 2,50 & 0,40 \\
\hline $\begin{array}{l}\text { Posttest kemampuan } \\
\text { berpikir kritis }\end{array}$ & 3,01 & 0,37 \\
\hline $\begin{array}{l}\text { Pretest prestasi belajar } \\
\text { PPKn }\end{array}$ & 2,50 & 0,40 \\
\hline $\begin{array}{l}\text { Posttest prestasi } \\
\text { belajar PPKn }\end{array}$ & 3,73 & 0,17 \\
\hline
\end{tabular}

Tabel 1 menunjukkan bahwa rata-rata hasil posttest aspek kemampuan berpikir kritis dan prestasi belajar PPKn lebih tinggi daripada pretest. Perbedaan aspek kemampuan berpikir kritis mencapai 0,51, sementara pada aspek prestasi belajar PPKn selisihnya 1,23.

Pada kelas eksperimen 2 menggunakan model discovery learning dengan gaya belajar auditorial. Berdasarkan hasil penelitian, perbedaan hasil pretest dan posttest dapat dilihat pada Tabel 2.
Tabel 2. Perbedaan Hasil Pretest dan Posttest pada Kelas Eksperimen 2

\begin{tabular}{|c|c|c|}
\hline Jenis Tes & Mean & STD \\
\hline $\begin{array}{l}\text { Pretest kemampuan } \\
\text { berpikir kritis }\end{array}$ & 1,22 & 0,20 \\
\hline $\begin{array}{l}\text { Posttest kemampuan } \\
\text { berpikir kritis }\end{array}$ & 3,24 & 0,40 \\
\hline $\begin{array}{l}\text { Pretest prestasi belajar } \\
\text { PPKn }\end{array}$ & 2,59 & 0,51 \\
\hline $\begin{array}{l}\text { Posttest prestasi } \\
\text { belajar PPKn }\end{array}$ & 3,60 & 0,20 \\
\hline
\end{tabular}

Tabel 2 menunjukkan bahwa rata-rata hasil posttest aspek kemampuan berpikir kritis dan prestasi belajar PPKn lebih tinggi daripada pretest. Perbedaan aspek kemampuan berpikir kritis mencapai 2,02, sementara pada aspek prestasi belajar PPKn 1,01.

Selanjutkan kelas eksperimen 3 menggunakan model discovery learning dengan gaya belajar visual. Adapun perbedaan hasil pretest dan posttest dapat dilihat pada Tabel 3.

Tabel 3. Perbedaan Hasil Pretest dan Posttest pada Kelas Eksperimen 3

\begin{tabular}{lcc}
\hline \multicolumn{1}{c}{ Jenis Tes } & Mean & STD \\
\hline $\begin{array}{l}\text { Pretest kemampuan } \\
\text { berpikir kritis }\end{array}$ & 1,47 & 0,28 \\
$\begin{array}{l}\text { Posttest kemampuan } \\
\text { berpikir kritis }\end{array}$ & 3,26 & 0,43 \\
$\begin{array}{l}\text { Pretest prestasi belajar } \\
\text { PPKn }\end{array}$ & 2,38 & 0,51 \\
$\begin{array}{l}\text { Posttest } \text { prestasi } \\
\text { belajar PPKn }\end{array}$ & 3,67 & 0,14 \\
\hline
\end{tabular}

Tabel 3 menunjukkan bahwa rata-rata hasil posttest aspek kemampuan berpikir kritis dan prestasi belajar PPKn lebih tinggi daripada pretest. Perbedaan aspek kemampuan berpikir kritis mencapai 1,79, sementara pada aspek prestasi belajar PPKn selisihnya 1,29.

Terakhir kelas eksperimen 4 menggunakan model PBL dengan gaya belajar auditorial. Berdasarkan hasil penelitian, perbedaan hasil pretest dan posttest dapat dilihat pada Tabel 4. 
Tabel 4. Perbedaan Hasil Pretest dan Posttest pada Kelas Eksperimen 4

\begin{tabular}{|c|c|c|}
\hline Jenis Tes & Mean & STD \\
\hline $\begin{array}{l}\text { Pretest kemampuan } \\
\text { berpikir kritis }\end{array}$ & 1,27 & 0,24 \\
\hline $\begin{array}{l}\text { Posttest kemampuan } \\
\text { berpikir kritis }\end{array}$ & 2,89 & 0,41 \\
\hline $\begin{array}{l}\text { Pretest prestasi belajar } \\
\text { PPKn }\end{array}$ & 2,93 & 0,30 \\
\hline $\begin{array}{l}\text { Posttest prestasi } \\
\text { belajar PPKn }\end{array}$ & 3,57 & 0,20 \\
\hline
\end{tabular}

Tabel 4 menunjukkan bahwa rata-rata hasil posttest aspek kemampuan berpikir kritis dan prestasi belajar PPKn lebih tinggi daripada hasil pretest. Perbedaan aspek kemampuan berpikir kritis mencapai 1,62, sementara pada aspek prestasi belajar PPKn selisihnya 0,64.

Hasil penelitian pada semua kelas eksperimen menunjukkan bahwa rata-rata hasil posttest lebih tinggi daripada hasil pretest. Artinya ada perubahan antara diberi perlakuan dan setelah diberi perlakuan. Perubahan yang paling terlihat adalah pada aspek kemampuan berpikir kritis.

Uji Hipotesis dan Pembahasan

Hipotesis pertama berbunyi terdapat perbedaan pengaruh antara kelas eksperimen dalam pembelajaran PPKn yang menggunakan model discovery learning dengan kelas yang menggunakan model PBL terhadap kemampuan berpikir kritis dan prestasi belajar PPKn. Hipotesis statistik pada hipotesis pertama diuraikan sebagai berikut.

$\mathrm{H}_{0}: \mu \mathrm{DL}=\mu \mathrm{PBL}$

$\mathrm{H}_{1}: \mu \mathrm{DL}>\mu \mathrm{PBL}$

Kriteria yang digunakan dalam uji statistik menggunakan Two-way Anova berdasarkan hasil analisis jika nilai signifikansi kurang dari 0,05 $(p<0,05)$ maka $\mathrm{H}_{0}$ ditolak dan $\mathrm{H}_{1}$ diterima. Hasil rangkuman uji hipotesis kemampuan berpikir kritis dapat dilihat pada Tabel 5 .

Tabel 5. Ringkasan Two Way Anova Perbandingan antara Model DL dan PBL dalam Pengaruh terhadap Kemampuan Berpikir Kritis Peserta Didik

\begin{tabular}{lccc}
\hline \multicolumn{1}{c}{ Kategori } & $\begin{array}{c}\text { Mean } \\
\text { Score }\end{array}$ & F & $\begin{array}{c}\text { Nilai } \\
\boldsymbol{p}\end{array}$ \\
\hline Model DL & 81,250 & \multirow{2}{*}{10,847} & 0,002 \\
Model PBL & 73,750 & & \\
\hline
\end{tabular}

Selanjutnya hasil rangkuman uji hipotesis prestasi belajar PPKn dapat dilihat pada Tabel 6.

Tabel 6. Ringkasan Two Way Anova Perbandingan antara Model DL dan PBL dalam Pengaruh terhadap Prestasi Belajar PPKn

\begin{tabular}{lccc}
\hline \multicolumn{1}{c}{ Kategori } & $\begin{array}{c}\text { Mean } \\
\text { Score }\end{array}$ & F & $\begin{array}{c}\text { Nilai } \\
\boldsymbol{p}\end{array}$ \\
\hline Model DL & 91,400 & \multirow{2}{*}{9,791} & 0,003 \\
Model PBL & 91,000 & & \\
\hline
\end{tabular}

Pada kelas eksperimen 1 nilai signifikansi kemampuan berpikir kritis sebesar 0,002 dan nilai signifikansi prestasi belajar PPKn sebesar 0,003. Mean score kemampuan berpikir kritis dengan penerapan model discovery learning sebesar 81,25 sedangkan mean score kemampuan berpikir kritis dengan penerapan model PBL sebesar 73,75. Mean score prestasi belajar PPKn dengan penerapan model discovery learning sebesar 91,40 sedangkan mean score prestasi belajar PPKn dengan penerapan model PBL sebesar 91,00.

Berdasarkan kriteria yang digunakan, diketahui nilai signifikansi lebih kecil dari 0,05 $(0,002<0,05)$ untuk kemampuan berpikir kritis dan nilai signifikansi lebih kecil dari 0,05 $(0,003<0,05)$ untuk prestasi belajar PPKn. Dengan demikian hipotesis pertama yang menyebutkan bahwa terdapat perbedaan pengaruh antara kelas eksperimen dalam pembelajaran PPKn yang menggunakan model discovery learning dengan kelas yang menggunakan model PBL terhadap kemampuan berpikir kritis dan prestasi belajar PPKn dapat dinyatakan diterima. Kemampuan berpikir kritis dan prestasi belajar PPKn dengan menggunakan model discovery learning lebih tinggi dibandingkan dengan model PBL.

Untuk mengetahui perbedaan aspek kemampuan berpikir kritis dan aspek prestasi belajar PPKn antara kelas eksperimen dalam pembelajaran menggunakan model discovery learning dengan kelas yang menggunakan model PBL diketahui dari mean score. Perbedaan mean score kemampuan berpikir kritis masing-masing kelas eksperimen dapat dilihat pada Gambar 1 . 


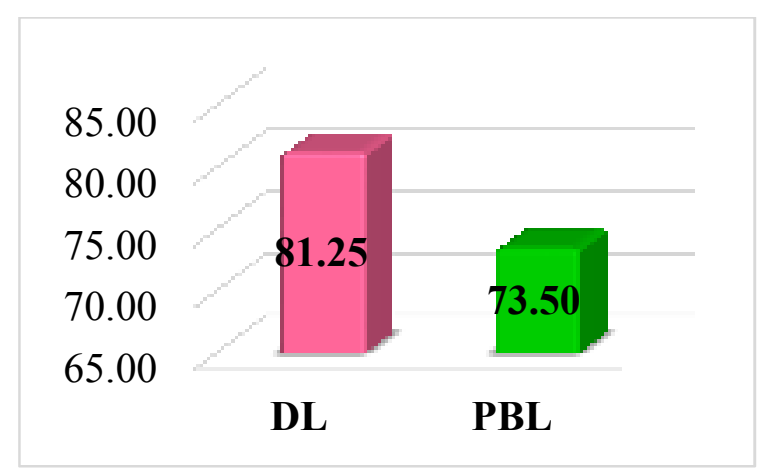

Gambar 1. Perbedaan Mean Score Kemampuan Berpikir Kritis Masing-Masing Kelas Eksperimen

Sedangkan perbedaan mean score prestasi belajar PPKn masing-masing kelas eksperimen dapat dilihat pada Gambar 2.

90.80

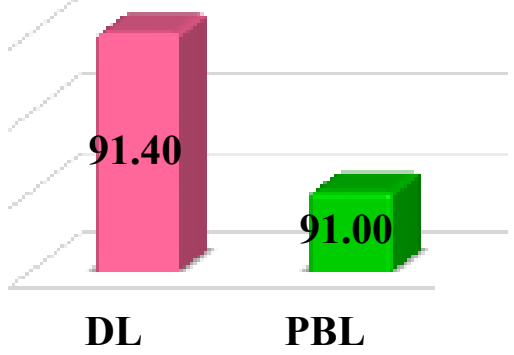

Gambar 2. Perbedaan Mean Score Prestasi Belajar PPKn Masing-Masing Kelas Eksperimen

Gambar 1 dan Gambar 2 menunjukkan bahwa penerapan model discovery learning lebih berpengaruh dibandingkan penerapan model PBL terhadap kemampuan berpikir kritis dan prestasi belajar PPKn.

Hasil penelitian ini menguatkan penelitian terdahulu, yaitu penelitian yang dilakukan oleh Mubarok \& Sulistyo (2014) tentang penerapan model pembelajaran discovery learning terhadap hasil belajar peserta didik. Hasil penelitian tersebut menunjukkan bahwa dengan menggunakan model discovery learning maka proses pembelajaran menjadi lebih menarik sehingga dapat meningkatkan hasil belajar peserta didik. Penelitian ini sejalan dengan pernyataan Moore (2009, p.178) bahwa discovery learning merupakan sarana pembelajaran yang melibatkan peserta didik dalam pemecahan masalah untuk mengembangkan keterampilan maupun pengetahuan. Maksudnya model discovery learning dapat digunakan sebagai sarana pembelajaran untuk mengembangkan keterampilan berpikir maupun pengetahuan kepada peserta didik.

Menurut Hanafiah dan Suhana (2009, p.78), penerapan model discovery learning mampu membangun komitmen di kalangan peserta didik untuk belajar yang diwujudkan dengan keterlibatan, kesungguhan dan loyalitas dalam mencari dan menemukan sesuatu dalam proses pembelajaran. Artinya, dengan menggunakan model discovery learning peserta didik mampu mengembangkan motivasi untuk mencari dan menemukan pengetahuan secara mandiri. Hal ini didukung oleh Joolingen $(1999$, p.386) yang menyatakan bahwa discovery learning merupakan model pembelajaran dimana peserta didik membangun pengetahuan mereka sendiri dengan bereksperimen sesuai dengan pengetahuan peserta didik sendiri serta menyimpulkan hasil dari pembelajaran yang telah diperoleh.

Penerapan model discovery learning pada kelas eksperimen mendorong peserta didik berpartisipasi aktif dalam membangun pengetahuannya. Model discovery learning memberikan kesempatan peserta didik untuk melakukan proses penyelidikan sehingga memberikan pengalaman langsung untuk menentukan konsep. Hal ini seperti yang diungkapkan oleh Trowbridge \& Bybee (1986, p.182) bahwa proses kognitif pada discovery meliputi mengamati (observing), mengelompokkan (classifying), mengukur (meansuring), memprediksi (predicting), menjelaskan (describing), dan menyimpulkan (inferring). Selain itu, dalam model discovery learning terdapat tahapan hypothesis generation sehingga dapat meningkatkan penalaran dan kemampuan berpikir bebas (kreatif) peserta didik serta menemukan dan memecahkan masalah tanpa bantuan orang lain (Veerman, 2002, p.8). Dengan demikian pada akhirnya peserta didik dapat belajar menumbuhkan kemampuan bepikir kritis terhadap materi yang dipelajari serta di sisi lain juga mampu meningkatkan prestasi belajarnya.

Meskipun penerapan model discovery learning lebih berpengaruh dibandingkan penerapan model PBL, akan tetapi model PBL juga memberikan pengaruh yang signifikan terhadap kemampuan berpikir kritis dan prestasi belajar PPKn peserta didik kelas VIII SMP Negeri 4 Kalasan. Hal ini menguatkan penelitian terdahulu, yaitu penelitian yang dilakukan oleh Primartadi (2013) meneliti tentang pengaruh metode STAD dan PBL 
terhadap hasil belajar ditinjau dari potensi akademik siswa SMK otomotif. Hasil penelitian tersebut menunjukkan bahwa melalui penerapan model PBL dapat meningkatkan hasil belajar peserta didik. Selain itu dalam penelitian Murwantono \& Sukidjo (2015) tentang peningkatan hasil belajar IPS dengan model PBL berbantuan media stimulan gambar menunjukkan hasil bahwa penerapan model PBL dapat meingkatkan hasil belajar peserta didik. Penelitian ini sejalan dengan pernyataan Dunlap (2005, p.65) bahwa model PBL merupakan pembelajaran yang menggunakan pemecahan masalah dunia nyata, membantu peserta didik memperoleh pengetahuan dan keterampilan yang diinginkan pada tempat dimana mereka belajar.

Dalam penerapan model PBL pada kelas eksperimen, peserta didik diberikan permasalahan dan dituntut untuk memecahkan permasalahan tersebut. Permasalahan yang diangkat dalam proses pembelajaran terkait isuisu kontroversial. Hal didukung pernyataan Arends (2012, p.397), bahwa salah satu karakteristik model PBL adalah driving questions or problem. Artinya bahwa model PBL diorganisasikan berdasarkan masalahmasalah kehidupan nyata. Peserta didik dihadapkan dengan masalah yang tidak dapat diberi jawaban-jawaban sederhana dan mengandung berbagai solusi agar menarik dan memotivasi peserta didik terlibat aktif. Sejalan dengan itu, Arends \& Kilcher (2010, p.326) mengungkapkan model PBL merupakan pembelajaran yang berpusat pada peserta didik, masalah yang digunakan bersifat tidak terstruktur dan menggunakan konteks dunia nyata. Melalui permasalahan dunia nyata yang kompleks, peserta didik lebih termotivasi dalam mengidentifikasi masalah, serta belajar dengan menggunakan prinsip-prinsip ilmiah dalam mencari solusi.

Hipotesis kedua yang berbunyi terdapat perbedaan pengaruh antara kelas eksperimen dalam pembelajaran PPKn yang menggunakan model discovery learning dengan kelas yang menggunakan model PBL terhadap kemampuan berpikir kritis dan prestasi belajar PPKn pada kelompok peserta didik gaya belajar visual. Hipotesis statistik pada hipotesis kedua diuraikan sebagai berikut.

$\mathrm{H}_{0}: \mu \mathrm{DLGV}=\mu \mathrm{PBLGV}$

$\mathrm{H}_{1}: \mu \mathrm{DLGV}>\mu \mathrm{PBLGV}$

Kriteria yang digunakan dalam uji statistik menggunakan Two-way Anova berdasarkan hasil analisis jika nilai signifikansi kurang dari $0,05(p<0,05)$ maka $\mathrm{H}_{0}$ ditolak dan $\mathrm{H}_{1}$ diterima. Hasil rangkuman uji hipotesis kemampuan berpikir kritis dapat dilihat pada Tabel 7.

Tabel 7. Ringkasan Two Way Anova Perbandingan antara Model DL dan PBL menurut Gaya Belajar Visual dalam Pengaruh terhadap Kemampuan Berpikir Kritis Peserta Didik

\begin{tabular}{lcc}
\hline \multicolumn{1}{c}{ Kategori } & F & Nilai $\boldsymbol{p}$ \\
\hline $\begin{array}{l}\text { Model DL } \\
\text { Model PBL }\end{array}$ & 10,847 & 0,002 \\
Gaya Belajar & 0,591 & 0,044 \\
Visual & \\
\hline
\end{tabular}

Selanjutnya hasil rangkuman uji hipotesis prestasi belajar PPKn dapat dilihat pada Tabel 8 .

Tabel 8. Ringkasan Two Way Anova

Perbandingan antara Model DL dan PBL menurut Gaya Belajar Visual dalam Pengaruh terhadap Prestasi Belajar PPKn

\begin{tabular}{lcc}
\hline \multicolumn{1}{c}{ Kategori } & F & Nilai $\boldsymbol{p}$ \\
\hline $\begin{array}{l}\text { Model DL } \\
\text { Model PBL }\end{array}$ & 9,791 & 0,003 \\
$\begin{array}{l}\text { Gaya Belajar } \\
\text { Visual }\end{array}$ & 8,009 & 0,006 \\
\hline
\end{tabular}

Mean score kemampuan berpikir kritis masing-masing kelas ekperimen pada kelompok gaya belajar visual disajikan pada Tabel 9 .

Tabel 9. Mean Score Kemampuan Berpikir

Kritis Masing-Masing Kelas Ekperimen Pada Kelompok Gaya Belajar Visual

\begin{tabular}{|c|c|}
\hline \multirow{2}{*}{ Gaya Belajar } & Model Pembelajaran \\
\hline & PBL \\
\hline Visual & 81,500 \\
\hline
\end{tabular}

Sedangkan mean score prestasi belajar PPKn masing-masing kelas ekperimen pada kelompok gaya belajar visual disajikan pada Tabel 10 .

Tabel 10. Mean Score Prestasi Belajar PPKn Masing-Masing Kelas Ekperimen Pada Kelompok Gaya Belajar Visual

\begin{tabular}{ccc}
\hline $\begin{array}{c}\text { Gaya } \\
\text { Belajar }\end{array}$ & \multicolumn{2}{c}{$\begin{array}{c}\text { Model Pembelajaran } \\
\text { DL }\end{array}$} \\
\hline Visual & 93,400 & 91,800 \\
\hline
\end{tabular}

Pada kelas eksperimen 2 nilai signifikansi pengaruh gaya belajar visual 
terhadap kemampuan berpikir kritis sebesar 0,044 dan nilai signifikansi pengaruh gaya belajar visual terhadap prestasi belajar PPKn sebesar 0,006. Mean score kemampuan berpikir kritis pada kelompok gaya belajar visual dengan penerapan model discovery learning sebesar 81,50 sedangkan mean score kemampuan berpikir kritis pada kelompok gaya belajar visual dengan penerapan model PBL sebesar 75,25. Mean score prestasi belajar PPKn pada kelompok gaya belajar visual dengan penerapan model discovery learning sebesar 93,40 sedangkan mean score prestasi belajar PPKn pada kelompok gaya belajar visual dengan penerapan model PBL sebesar 91,80.

Berdasarkan kriteria yang digunakan, diketahui nilai signifikansi lebih kecil dari 0,05 $(0,044<0,05)$ untuk kemampuan berpikir kritis dan nilai signifikansi lebih kecil dari 0,05 $(0,006<0,05)$ untuk prestasi belajar PPKn. Dengan demikian hipotesis kedua yang menyebutkan bahwa terdapat perbedaan pengaruh antara kelas eksperimen dalam pembelajaran PPKn yang menggunakan model discovery learning dengan kelas yang menggunakan model PBL terhadap kemampuan berpikir kritis dan prestasi belajar PPKn pada kelompok peserta didik gaya belajar visual dapat dinyatakan diterima. Kemampuan berpikir kritis dan prestasi belajar PPKn dengan menggunakan model discovery learning lebih tinggi dibandingkan dengan model PBL pada kelompok peserta didik gaya belajar visual.

Untuk mengetahui perbedaan aspek kemampuan berpikir kritis dan aspek prestasi belajar PPKn antara kelas eksperimen dalam pembelajaran menggunakan model discovery learning dengan kelas yang menggunakan model PBL pada kelompok gaya belajar visual diketahui dari mean score. Perbedaan mean score kemampuan berpikir kritis masingmasing kelas eksperimen kelompok gaya belajar visual dapat dilihat pada Gambar 3 .

85.00

80.00

75.00

70.00

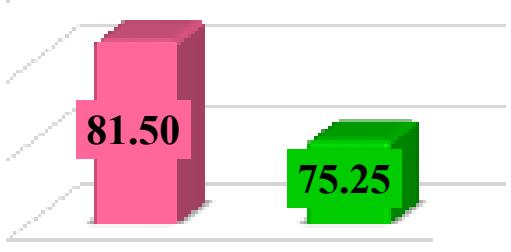

DL PBL
Gambar 3. Perbedaan Mean Score Kemampuan Berpikir Kritis Masing-Masing Kelas Eksperimen Kelompok Gaya Belajar Visual

Sedangkan perbedaan mean score prestasi belajar PPKn masing-masing kelas eksperimen kelompok gaya belajar visual dapat dilihat pada Gambar 4 berikut.

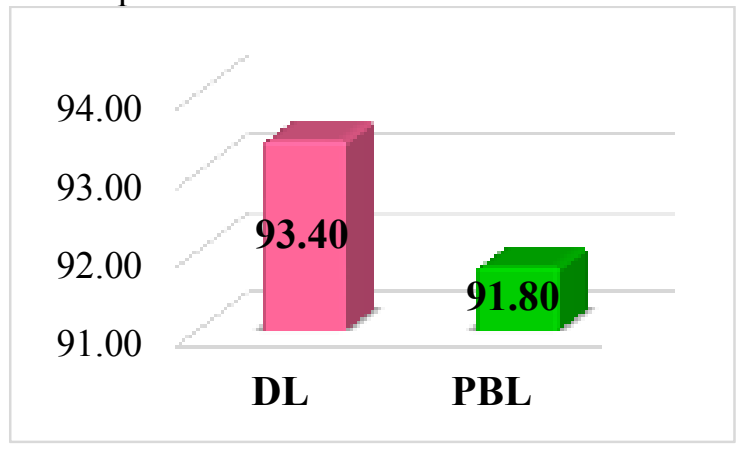

Gambar 4. Perbedaan Mean Score Prestasi

Belajar PPKn Masing-Masing Kelas

Eksperimen Kelompok Gaya Belajar Visual

Gambar 3 dan Gambar 4 menunjukkan bahwa penerapan model discovery learning lebih berpengaruh dibandingkan penerapan model PBL terhadap kemampuan berpikir kritis dan prestasi belajar PPKn pada kelompok peserta didik gaya belajar visual.

Hasil penelitian ini menguatkan penelitian terdahulu, yaitu penelitian yang dilakukan oleh O'Leary \& Stewart (2013) tentang the interaction of learning style and teaching methodologies in accounting ethical instruction. Hasil penelitian tersebut menunjukkan bahwa gaya belajar yang sesuai dengan metode pengajaran memiliki pengaruh yang signifikan terhadap hasil belajar Akutansi peserta didik. Penelitian ini sejalan dengan pernyataan Silberman (2011, p.28) bahwa sebagai pendidik harus memahami peserta didik yang memiliki berbagai macam cara belajar. Maksudnya dengan memahami gaya belajar peserta didik dapat membantu menentukan model pembelajaran yang mendukung terserapnya informasi kepada peserta didik.

Hipotesis ketiga yang berbunyi terdapat perbedaan pengaruh antara kelas eksperimen dalam pembelajaran PPKn yang menggunakan model discovery learning dengan kelas yang menggunakan model PBL terhadap kemampuan berpikir kritis dan prestasi belajar PPKn pada kelompok peserta didik gaya belajar auditorial. Hipotesis statistik pada hipotesis ketiga diuraikan sebagai berikut. 
$\mathrm{H}_{0}: \mu \mathrm{DLGA}=\mu \mathrm{PBLGA}$

$\mathrm{H}_{1}: \mu$ DLGA $>\mu$ PBLGA

Kriteria yang digunakan dalam uji statistik menggunakan Two-way Anova berdasarkan hasil analisis jika nilai signifikansi kurang dari 0,05 $(p<0,05)$ maka $\mathrm{H}_{0}$ ditolak dan $\mathrm{H}_{1}$ diterima. Hasil rangkuman uji hipotesis kemampuan berpikir kritis dapat dilihat pada Tabel 11.

Tabel 11. Ringkasan Two Way Anova Perbandingan antara Model DL dan PBL menurut Gaya Belajar Auditorial dalam Pengaruh terhadap Kemampuan Berpikir Kritis Peserta Didik

\begin{tabular}{lcc}
\hline \multicolumn{1}{c}{ Kategori } & F & Nilai $\boldsymbol{p}$ \\
\hline $\begin{array}{l}\text { Model DL } \\
\text { Model PBL } \\
\text { Gaya Belajar }\end{array}$ & 10,847 & 0,002 \\
Auditorial & 0,591 & 0,044 \\
\hline
\end{tabular}

Selanjutnya hasil rangkuman uji hipotesis prestasi belajar PPKn dapat dilihat pada Tabel 12.

Tabel 12. Ringkasan Two Way Anova Perbandingan antara Model DL dan PBL menurut Gaya Belajar Auditorial dalam Pengaruh terhadap Prestasi Belajar PPKn

\begin{tabular}{lcc}
\hline \multicolumn{1}{c}{ Kategori } & F & Nilai $\boldsymbol{p}$ \\
\hline $\begin{array}{l}\text { Model DL } \\
\text { Model PBL }\end{array}$ & 9,791 & 0,003 \\
$\begin{array}{l}\text { Gaya Belajar } \\
\text { Auditorial }\end{array}$ & 8,009 & 0,006 \\
\hline
\end{tabular}

Mean score kemampuan berpikir kritis masing-masing kelas ekperimen pada kelompok gaya belajar auditorial disajikan pada Tabel 13.

Tabel 13. Mean Score Kemampuan Berpikir Kritis Masing-Masing Kelas Ekperimen Pada Kelompok Gaya Belajar Auditorial

\begin{tabular}{lcc}
\hline \multirow{2}{*}{ Gaya Belajar } & \multicolumn{2}{c}{$\begin{array}{c}\text { Model Pembelajaran } \\
\text { DL }\end{array}$} \\
\hline Auditorial & 81,000 & 72,250 \\
\hline
\end{tabular}

Sedangkan mean score prestasi belajar PPKn masing-masing kelas ekperimen pada kelompok gaya belajar auditorial disajikan pada Tabel 14 .
Tabel 14. Mean Score Prestasi Belajar PPKn Masing-Masing Kelas Ekperimen Pada Kelompok Gaya Belajar Auditorial

\begin{tabular}{|c|c|}
\hline Gaya & Model Pembelajaran \\
\hline Belajar & PBL \\
\hline Auditorial & 90,200 \\
\hline
\end{tabular}

Pada kelas eksperimen 3 nilai signifikansi pengaruh gaya belajar auditorial terhadap kemampuan berpikir kritis sebesar 0,044 dan nilai signifikansi pengaruh gaya belajar visual terhadap prestasi belajar PPKn sebesar 0,006. Mean score kemampuan berpikir kritis pada kelompok gaya belajar auditorial dengan penerapan model discovery learning sebesar 81,00 sedangkan mean score kemampuan berpikir kritis pada kelompok gaya belajar auditorial dengan penerapan model PBL sebesar 72,25. Mean score prestasi belajar PPKn pada kelompok gaya belajar auditorial dengan penerapan model discovery learning sebesar 90,20 sedangkan mean score prestasi belajar PPKn pada kelompok gaya belajar auditorial dengan penerapan model PBL sebesar 89,40.

Berdasarkan kriteria yang digunakan, diketahui nilai signifikansi lebih kecil dari 0,05 $(0,044<0,05)$ untuk kemampuan berpikir kritis dan nilai signifikansi lebih kecil dari 0,05 $(0,006<0,05)$ untuk prestasi belajar PPKn. Dengan demikian hipotesis ketiga yang menyebutkan bahwa terdapat perbedaan pengaruh antara kelas eksperimen dalam pembelajaran PPKn yang menggunakan model discovery learning dengan kelas yang menggunakan model PBL terhadap kemampuan berpikir kritis dan prestasi belajar PPKn pada kelompok peserta didik gaya belajar auditorial dapat dinyatakan diterima. Kemampuan berpikir kritis dan prestasi belajar PPKn dengan menggunakan model discovery learning lebih tinggi dibandingkan dengan model PBL pada kelompok peserta didik gaya belajar auditorial.

Untuk mengetahui perbedaan aspek kemampuan berpikir kritis dan aspek prestasi belajar PPKn antara kelas eksperimen dalam pembelajaran menggunakan model discovery learning dengan kelas yang menggunakan model PBL pada kelompok gaya belajar auditorial diketahui dari mean score. Perbedaan mean score kemampuan berpikir kritis masingmasing kelas eksperimen dapat dilihat pada Gambar 5. 


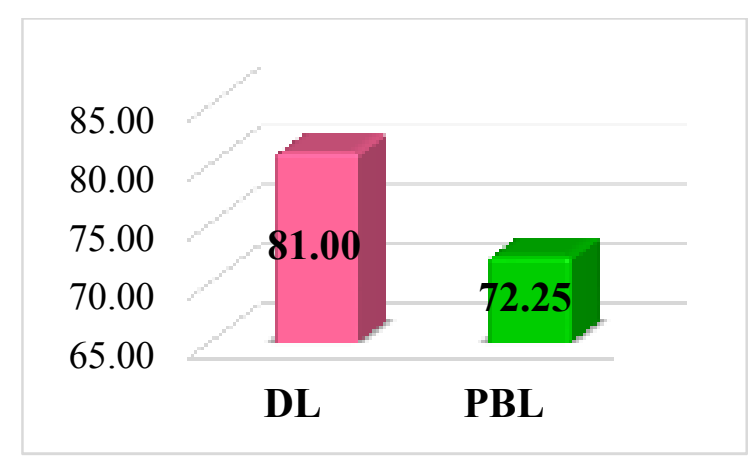

Gambar 5. Perbedaan Mean Score Kemampuan Berpikir Kritis Masing-Masing Kelas Eksperimen Kelompok Gaya Belajar Auditorial

Sedangkan perbedaan mean score prestasi belajar PPKn masing-masing kelas eksperimen kelompok gaya belajar auditorial dapat dilihat pada Gambar 6 .

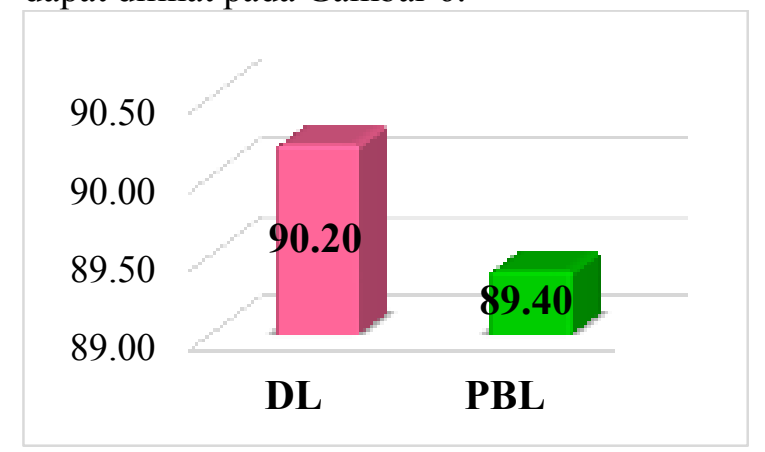

Gambar 6. Perbedaan Mean Score Prestasi Belajar PPKn Masing-Masing Kelas Eksperimen Kelompok Gaya Belajar Auditorial

Gambar 5 dan Gambar 6 menunjukkan bahwa penerapan model discovery learning lebih berpengaruh dibandingkan penerapan model PBL terhadap kemampuan berpikir kritis dan prestasi belajar PPKn pada kelompok peserta didik gaya belajar auditorial.

Hasil penelitian ini menguatkan penelitian terdahulu, yaitu penelitian yang dilakukan oleh Utami \& Gafur (2015) meneliti tentang pengaruh metode pembelajaran dan gaya belajar peserta didik terhadap hasil belajar IPS di SMP Negeri Di Kota Yogyakarta. Dalam penelitiannya menyatakan bahwa dengan mengetahui gaya belajar peserta didik memudahkan guru dalam melaksanakan pembelajaran di kelas, sehingga mampu meningkatkan hasil belajar peserta didik. Penelitian ini sejalan dengan pernyataan DePorter, Reardon \& Nourie (2010, p.242) yang menyatakan bahwa dengan mengetahui gaya belajar masing-masing, peserta didik mampu menyerap bahan pelajaran dengan cara yang terbaik.
Hipotesis keempat yang berbunyi terdapat interaksi antara model pembelajaran dan gaya belajar terhadap kemampuan berpikir kritis dan prestasi belajar PPKn peserta didik kelas VIII SMP Negeri 4 Kalasan. Hipotesis statistik pada hipotesis keempat diuraikan sebagai berikut.

$\mathrm{H}_{0}$ : Tidak ada interaksi A X B

$\mathrm{H}_{1}$ : Ada interaksi A X B

Kriteria yang digunakan dalam uji statistik menggunakan Two-way Anova berdasarkan hasil analisis jika nilai signifikansi kurang dari $0,05(p<0,05)$ maka $\mathrm{H}_{0}$ ditolak dan $\mathrm{H}_{1}$ diterima. Hasil rangkuman uji hipotesis kemampuan berpikir kritis dapat dilihat pada Tabel 15.

Tabel 15. Ringkasan Two Way Anova Perbandingan antara Model DL dan PBL menurut Gaya Belajar dalam Pengaruh terhadap

Kemampuan Berpikir Kritis Peserta Didik

\begin{tabular}{lccc}
\hline \multicolumn{1}{c}{ Kategori } & $\begin{array}{c}\text { Mean } \\
\text { Score }\end{array}$ & F & Nilai $\boldsymbol{p}$ \\
\hline Model DL & 81,250 & 10,847 & 0,002 \\
Model PBL & 73,750 & & \\
Gaya Belajar & 78,375 & & \\
$\begin{array}{l}\text { Visual } \\
\text { Gaya Belajar }\end{array}$ & 76,625 & 0,591 & 0,044 \\
$\begin{array}{l}\text { Auditorial } \\
\text { Model*Gaya }\end{array}$ & - & 0,301 & 0,585 \\
Belajar & & & \\
\hline
\end{tabular}

Selanjutnya hasil rangkuman uji hipotesis prestasi belajar PPKn dapat dilihat pada Tabel 16.

Tabel 16. Ringkasan Two Way Anova

Perbandingan antara Model DL dan PBL menurut Gaya Belajar dalam Pengaruh terhadap Prestasi Belajar PPKn

\begin{tabular}{|c|c|c|c|}
\hline Kategori & $\begin{array}{l}\text { Mean } \\
\text { Score } \\
\end{array}$ & $\mathbf{F}$ & Nilai $p$ \\
\hline Model DL & 91,400 & \multirow{2}{*}{9,791} & \multirow{2}{*}{0,003} \\
\hline Model PBL & 91,000 & & \\
\hline $\begin{array}{l}\text { Gaya Belajar } \\
\text { Visual }\end{array}$ & 92,600 & \multirow[b]{2}{*}{8,009} & \multirow[b]{2}{*}{0,006} \\
\hline $\begin{array}{l}\text { Gaya Belajar } \\
\text { Auditorial }\end{array}$ & 89,800 & & \\
\hline $\begin{array}{l}\text { Model*Gaya } \\
\text { Belajar }\end{array}$ & - & 1,471 & 0,229 \\
\hline
\end{tabular}

Pada kelas eksperimen 4 nilai signifikansi model pembelajaran dengan gaya belajar mempengaruhi kemampuan berpikir kritis sebesar 0,585 dan nilai signifikansi model 
pembelajaran dengan gaya belajar mempengaruhi prestasi belajar PPKn sebesar 0,229 .

Berdasarkan kriteria yang digunakan, diketahui nilai signifikansi lebih besar dari 0,05 $(0,585>0,05)$ untuk kemampuan berpikir kritis dan nilai signifikansi lebih besar dari 0,05 $(0,229>0,05)$ untuk prestasi belajar PPKn. Dengan demikian hipotesis keempat yang menyebutkan bahwa terdapat interaksi antara model pembelajaran dan gaya belajar terhadap kemampuan berpikir kritis dan prestasi belajar PPKn dinyatakan ditolak.

Pengaruh antara model pembelajaran dengan gaya belajar dalam mempengaruhi kemampuan berpikir kritis sebesar 13,4\%. Hal ini terbukti dari perhitungan $R$ Squared sebesar $=0,134$ atau 13,4\%. Sisanya sebesar $86,6 \%$ merupakan variabel lain di luar model pembelajaran dan gaya belajar yang memiliki pengaruh terhadap kemampuan berpikir kritis peserta didik. Selanjutnya pengaruh antara model pembelajaran dengan gaya belajar dalam mempengaruhi prestasi belajar PPKn sebesar $11,3 \%$. Hal ini terbukti dari perhitungan $R$ Squared sebesar $=0,113$ atau $11,3 \%$. Sisanya sebesar $88,7 \%$ merupakan variabel lain di luar model pembelajaran dan gaya belajar yang memiliki pengaruh terhadap prestasi belajar PPKn.

\section{Simpulan dan Saran}

Simpulan

Berdasarkan hasil penelitian dan pembahasan dapat disimpulkan: 1) terdapat perbedaan pengaruh antara model discovery learning dan model problem based learning terhadap kemampuan berpikir kritis $(0,002<$ $0,05)$ dan prestasi belajar PPKn $(0,003<0,05)$, ; 2) terdapat perbedaan pengaruh antara model discovery learning dan model problem based learning terhadap kemampuan berpikir kritis $(0,044<0,05)$ dan prestasi belajar PPKn $(0,006$ $<0,05)$ pada kelompok peserta didik gaya belajar visual; 3) terdapat perbedaan pengaruh antara model discovery learning dan model problem based learning terhadap kemampuan berpikir kritis $(0,044<0,05)$ dan prestasi belajar PPKn $(0,006<0,05)$ pada kelompok peserta didik gaya belajar auditorial; dan 4) tidak terdapat interaksi yang signifikan antara model pembelajaran dan gaya belajar terhadap kemampuan berpikir kritis $(0,585>0,05)$ dan prestasi belajar PPKn $(0,229>0,05)$.
Pembelajaran PPKn dengan model discovery learning pada kelompok peserta didik gaya belajar visual lebih unggul daripada model PBL baik kelompok peserta didik gaya belajar visual maupun auditorial terhadap kemampuan berpikir kritis dan prestasi belajar PPKn.

Saran

Berdasarkan hasil pembahasan dan kesimpulan penelitian, ada beberapa saran yang disampaikan. 1) Guru diharapkan menggunakan model pembelajaran yang inovatif seperti model discovery learning dan model PBL untuk meningkatkan kemampuan berpikir kritis dan prestasi belajar PPKn peserta didik pada materi tentang Hak Asasi Manusia. 2) Guru diharapkan dapat memadukan model pembelajaran yang disesuaikan dengan gaya belajar peserta didik agar pembelajaran lebih efektif. 3) Peneliti berikutnya diharapkan dapat memanfaatkan penelitian ini sebagai bahan acuan dalam melaksanakan penelitiannya dengan melengkapi keterbatasan dalam penelitian seperti keterbatasan waktu penelitian dalam setiap pertemuan mengakibatkan tidak semua kelompok (presenter) mendapat kesempatan untuk mempresentasikan jawaban hasil diskusi kelompoknya di depan kelas.

\section{Daftar Pustaka}

Afrizon, R., Ratnawulan, \& Fauzi, A. (2012). Peningkatan perilaku berkarakter dan keterampilan berpikir kritis siswa kelas IX MTsN Model Padang pada mata pelajaran IPA Fisika menggunakan model problem based instruction. Journal Penelitian Pembelajaran Fisika, 1, (1), 1-16.

Arends, R.I. (2012). Learning to teach. New York: McGraw-Hill Companies, Inc.

Arends, R.I., \& Kilcher, A. (2010). Teaching for student learning becoming an accomplished teacher. New York City: Routledge.

DePorter, B., \& Hernacki, M. (2015). Quantum learning: membiasakan belajar nyaman dan menyenangkan. (Terjemahan Alwiyah Abdurrahman). New York: Deli Publishing. (Buku asli diterbitkan tahun 1992).

DePorter, B., Reardon, M., \& Nourie, S.S. (2010). Quantum teaching: mempraktikkan quantum learning di ruang-ruang kelas. (Terjemahan 
Alwiyah Abdurrahman). New York: Deli Publishing. (Buku asli diterbitkan tahun 1999).

Dimyati \& Mujiono. (2002). Belajar dan pembelajaran. Jakarta: Gramedia.

Djamarah, S.B. \& Zein, A. (2006). Strategi belajar mengajar. Jakarta: Rineka Cipta.

Dunlap, J.C. (2005). Problem based and selfefficacy: how a capstone course prepares student for a profession. Educational Technology, Research and Development, 53, (1), 65-85.

Fatade, A.O., Mogari, D., \& Arigbabu, A.A. (2013). Effect of problem based learning on senior secondary school students achievements in further mathematics. Acta Didactica Napocencia, 6 (3), 27-44.

Gilakjani, A.P. (2012). Visual, auditory, kinaesthetic learning styles and their impacts on english language teaching. Journal of Studies in Education, 2, (1), 104-113.

Goodson, L. \& Rohani, F. (1998). Higher order thingking skills, definitons, teaching strategies, assessment. Thingking, 18, 1-22.

Halim, A. (2012). Pengaruh strategi pembelajaran dan gaya belajar terhadap hasil belajar Fisika Peserta didik SMPN 2 Secanggang kabupaten Langkat. Jurnal Tabularasa PPS Unimed, 9, 141-158.

Hanafiah, N., \& Suhana, C. (2009). Konsep strategi pembelajaran. Bandung: Refika Aditama.

Hartono. (2014). SPSS 16.0: analisis data statistika dan penelitian. Yogyakarta: Pustaka Pelajar.

Jhonson, D.W. (2002). Meaningful assesment: a manageable and cooperative process. Boston: Allyn Bacon.

Johnson, B.E. (1999). Contextual teaching and learning. California: Corwin Press.

Joolingen, W.V. (1999). Cognitive tools for discovery learning. International Journal of Artificial Intelligence in Education IJAIED), 10, 385-397.

Kementerian Pendidikan dan Kebudayaan. (2014). Peraturan Menteri Pendidikan dan Kebudayaan Nomor 58 tentang Kurikulum 2013 SMP/MTs.
Kyriacou, C. (2009). Effective teaching in school: theory and practice. Cheltenham: Nelson Thornes Ltd.

Lewis, A., \& Smith, D. (1993). Defining higher order thingking. College of Education The Ohio State University, 32, (3), 131137.

Moore, K.D. (2009). Effective instructional strategies: from theory to practice. Los Angeles: Sage Publications, Inc.

Mubarok, C., \& Sulistyo, E. (2014). Penerapan model pembelajaran discovery learning terhadap hasil belajar Peserta didik kelas X Tav pada standar kompetensi melakukan instalasi sound system di SMK Negeri 2 Surabaya. Jurnal Pendidikan Teknik Elektro, 3 (1), 215221.

Murwantono, M., \& Sukidjo, S. (2015). Peningkatan hasil belajar IPS dengan model problem based learning berbantuan media stimulan gambar. Harmoni Sosial: Jurnal Pendidikan IPS, 2(1), 30-41. doi:http://dx.doi.org/10.21831/hsjpi.v2i 1.4601

O'Leary, C. \& Stewart, J. (2013). The interaction of learning style and teaching methodologies in accounting ethical instruction. Journal of Business Ethics, 113, (2), 225-241.Ojimba, D.P. (2013). School variables and senior secondary students achievement in mathematics in rivers state, Nigeria. Mediterranean Journal of Social Sciences, 4, (2), 709-718.

Pacific Policy Research Center. (2010). 21 $1^{s t}$ century skills for students and teachers. Honolulu: Kamehameha Schools, Reseach \& Evaluation Division.

Primartadi, A. (2013). Pengaruh metode student teams-achievement division (STAD) dan problem based learning terhadap hasil belajar ditinjau dari potensi akademik siswa SMK otomotif. Jurnal Pendidikan Vokasi, 2(2). doi:http://dx.doi.org/10.21831/jpv.v2i2. 1024

Sanjaya, W. (2013). Strategi pembelajaran: berorientasi standar proses pendidikan. Jakarta: Kencana.

Santrock, J.W. (2009). Psikologi pendidikan. (Terjemahan Diana Angelica). New York: McGraw-Hill. (Buku asli diterbitkan tahun 2008). 
Sapriya. (2015). Pendidikan IPS konsep dan pembelajaran. Bandung: Remaja Rosdakarya.

Saputra, E. (2012). Eksistensi PKn sebagai pendidikan nilai dalam mebangun karakter bangsa. Jurnal Tingkap, 8 (2), 145-158.

Shen, P.D., Lee, T.H., \& Tsai, C. W. (2007). Applying web-enabled problem-based learning and self-regulated learning to enhance computing skills of Taiwan's vocational students: a quasiexperimental study of a short-term module. Electronic Journal of $e$ Learning, 5 (2), 147-156.

Silberman, M.L. (2011). Active learning: 101 strategies to teach any subject. (Terjemahan Raisul Muttaqien). Boston: Allyn and Bacon. (Buku asli diterbitkan tahun 1996).

Syah, M. (2013). Psikologi pendidikan dengan pendekatan baru. Bandung: PT. Remaja Rosdakarya.

Trowbridge, L.W., \& Bybee, R.W. (1986). Becoming a secondary school science teacher. Columbus: Merrill Publishing Company.

Tutton, T. (2013). Learning styles and Sunday school kids. Siclair: Lincoln Ave.

Utami, P.S., \& Gafur, A. (2015). Pengaruh metode pembelajaran dan gaya belajar Peserta didik terhadap hasil belajar IPS di SMP Negeri Di Kota Yogyakarta. Jurnal Pendidikan IPS, 2 (1), 97-103.

Veerman, K. (2002). Intelligent support for discovery. Enschede: Twente University Press.

\section{Profil Singkat}

Fitri Mutmainnah, putri kelahiran Kediri, 7 Mei 1989. Anak kedua dari dua bersaudara. Jenjang pendidikan dasar dan menengah diselesaikan di Kabupaten Kediri. Gelar sarjana diperoleh dari Universitas Negeri Surabaya Prodi PPKn lulus tahun 2011. Saat ini sedang mengambil S2 prodi PPKn Pascasarjana Universitas Negeri Yogyakarta angkatan 2015. 